\title{
Design and Expression Optimization of a Chimeric Derivative of NetB, Alpha- Toxin and Metallopeptidase Proteins as a Subunit Vaccine Against Clostridium perfringens
}

\author{
Camellia Katalani $^{1}$, Ghorbanali Nematzadeh ${ }^{2} *$, Gholamreza Ahmadian ${ }^{3} * *$, Jafar Amani $^{4}$, Ghafar Kiani ${ }^{5}$, Parastoo \\ Ehsani $^{5}$
}

\begin{abstract}
${ }^{1}$ Agriculture Science and Natural Resource University (SANRU), Faculty of Agricultural science. ${ }^{2}$ Sari Agriculture Science and Natural Resource University (SANRU), Genetics and Agricultural Biotechnology Institute of Tabarestan (GABIT). ${ }^{3}$ Department of Industrial and Environmental Biotechnology, National Institute of Genetic Engineering and Biotechnology (NIGEB). ${ }^{4}$ Applied Microbiology Research Center, Baqiyatallah University of Medical Sciences . ${ }^{5}$ Department of Molecular Biology, Pasteur Institute of Iran
\end{abstract}

\begin{tabular}{|c|c|}
\hline A R T I C L E I N F O & A B S T R A C T \\
\hline Original Article & $\begin{array}{l}\text { Avian necrotic enteritis (NE) is a multi-virulence disease caused by the bacteriu } \\
\text { Clostridium perfringens. Several toxins of this bacteria are components of differe }\end{array}$ \\
\hline VacRes, 2019 & \\
\hline Vol, 6, No.1, 5 - 12 & tein composed of im \\
\hline Received: June 11, 2019 & proteins (NAM) wa \\
\hline Accepted: July 09, 2019 & important for \\
\hline Pasteur Institute of Iran & $x^{2}$ \\
\hline *Corresponding Author: Ghorbanali & re condition. 10 this end, induction c \\
\hline \multirow{2}{*}{ Nematzadeh, Genetics and } & ty prior induction $(\mathrm{OD} 600 \mathrm{~nm})$, IPTG concentrat \\
\hline & ime were modified. The statistical analysis $r$ \\
\hline $\begin{array}{l}\text { Agricultural Biotechnology Institute of } \\
\text { Tabarestan (GABIT), Sari Agriculture }\end{array}$ & ignificant effects on production an \\
\hline Science and Natural Resource & ion of soluble rNAM was ac \\
\hline University (SANRU), Sari, Iran. & the pre-induction OD and \\
\hline Email: gh.nematzadeh@sanru.ac.ir & respectively in $8 \mathrm{~h}$ after induction. Our study indicated that the RSM method $\mathrm{i}$ \\
\hline $\begin{array}{l}\text { Tel/Fax: } \\
(+98) 1133687744 /(+98) 1133687747\end{array}$ & ategy for protein expression improvement which is considered as a maj \\
\hline \multirow{2}{*}{$\begin{array}{ll}* * \text { Co-Corresponding } & \text { Author: } \\
\text { Gholamreza Ahmadian, } & \text { National }\end{array}$} & roduction of vaccine candidate and other recombinant proteins usir \\
\hline & \\
\hline
\end{tabular}

Institute for Genetic Engineering and

Biotechnology, Tehran, Iran.

Email: ahmadian@nigeb.ac.ir

Tel/Fax: (+9821) 44580-351, (+9821)

912-4187608/ (+98)21 44580-366

KEYWORDS: subunit vaccine,

optimization, necrotic, enteritis, toxin, RSM

\section{INTRODUCTION}

Necrotic enteritis (NE) is caused by clostridium perfringens type A, an anaerobic Gram-positive bacteria. Several virulence factors are involved in disease induction in chickens. In recent years protein based subunit vaccines have provided a safe and most attractive technology for protection against multifactorial disease like NE [10, 34]. Previous studies demonstrated that immunizing ability for protection against NE was associated with several virulence factors. The most important of these virulence factors are phospholipase $\mathrm{C}$ known as Alpha-toxin, $\beta$-pore forming toxin, NetB, and a zinc metallopeptidase protein $[7,8,28]$. Utilizing a fusion of non toxic variants of these proteins as a recombinant subunit vaccine candidate could enhance protective immunity $[31,6]$. 
To develop an effective subunit vaccine candidate against $\mathrm{NE}$, it is important to optimize in a suitable heterologous expression system.

To this end, E. coli, and Salmonella, were used to express recombinant toxin of NE [12]. E. coli expression system is one of the most attractive and well characterized expression system because of the fast growth, high yield and low cost of protein expression. In spite of these advantages, sometimes, high level production of soluble recombinant protein may be quiet challenging $[29,22]$. Generally, the aggregated proteins, known as inclusion bodies, are misfolded and therefore are biologically inactive. In many cases, solubilization and refolding of insoluble protein is a cumbersome and time consuming process and increase the complexity of downstream processing $[24,32$, 33]. To address these concerns, multiple strategies designed to improve solubility rates of the recombinant protein. One of the easy, inexpensive and efficient methods is to modify the culture conditions [23]. Starting time of induction, post-induction tezmperature, time and inducer concentration are the most parameters that affect the solubility $[3,26]$.

The conventional optimization method of 'one factor at a time' requires numerous experimental data set to describe the interaction between parameters and time consuming. To overcome these obstacles, an efficient statistical model is needed. Therefore, evaluating the independent variables and assessing the interaction among them and simultaneously utilizing randomization and replication are applied. Statistical approaches like response surface methodology (RSM) that is based on full factorial central composite design (CCD) is ideal in industrial biotechnology processes. Numerous biochemical processes, including recombinant protein expression utilizing RSM to estimate optimum operating conditions results in identifying minimum or maximum responses. The statistical design allows quick identification of the important parameters for screening and optimization culture conditions [20,23].

In this study, we designed a fusion trivalent protein including the immunogenic epitopes of Alfa-toxin, NetB and a metaloprotease proteins as a candidate vaccine against NE and optimized the expression of this fusion protein using statistical design.

\section{MATERIALS and METHODS}

\section{Materials, Plasmid and Expression System}

Bacterial cultures and kanamycin antibiotic were purchased from Sigma. Restriction enzymes were obtained from Thermo (US). PCR reagents were obtained from SinaClone (IRAN).

\section{Construction of Expression Plasmid}

The amino acid sequences and structure characteristics of three selected proteins for construction the fusion protein was retrieved from uniProtKB with accession number 4h56, $2 \mathrm{wxu}$, $5 \mathrm{kdj}$ for NetB, Alpha toxin and metalopeptidase protein, respectively. To make a fusion protein, the carboxy terminal of $\mathrm{NetB}$ and Alpha-toxin and a strongly immunogenic epitopes of Zinc metallopeptidase were joined with A(EAAAk)4A as a flexible helical linker. The fusion protein was back translated to nucleic acid and synthesized by Biomatic (Canada), the flanking restriction sites EcoRI and HindIII were inserted using p1 (ATAGAgaattcATGGTTTCTAATTCAATCGGA) and p2 (CATAAaagcttTTACTCTTCACCCAAAGCAA) primers (table 1).
Table 1. Rare codon analysis at after and before codon optimization based on codon usage of tobacco as host organism

\begin{tabular}{|c|c|c|c|c|}
\hline $\begin{array}{c}\text { Codon optimization } \\
\text { parameters }\end{array}$ & \multicolumn{2}{|c|}{ Before optimization } & \multicolumn{2}{c|}{ After optimization } \\
\cline { 2 - 5 } & Tobacco & $\boldsymbol{E}$. coli & Tobacco & $\boldsymbol{E}$. coli \\
\hline CAI & 0.85 & 0.63 & 0.93 & 0.63 \\
\hline GC\% & 31.76 & 31.76 & 35.69 & 35.69 \\
\hline CFD\% & 0 & 11 & 0 & 9 \\
\hline $\begin{array}{c}\text { Negative } \\
\text { CIS elements }\end{array}$ & 35 & 0 & 0 & 1 \\
\hline $\begin{array}{c}\text { Negative } \\
\text { repeat elements }\end{array}$ & 1 & 1 & 0 & 1 \\
\hline \multicolumn{2}{|c|}{ CAI: codon adaptation index, CFD: low frequency codon } \\
\hline
\end{tabular}

The NAM gene was then cloned into expression vector pET28a (+) (Novagene) under control of the strong T7 RNA polymerase promoter. This prokaryotic expression system was named as pET28-NAM. The resulting pET28a-NAM plasmid was introduced into E.coli BL21 (DE3) (Stratagene) cells according to heat shock method and grown in LB agar plate supplemented with $50 \mathrm{mg} / \mathrm{l}$ kanamycin. The optimization runs were carried out in $100 \mathrm{ml}$ Erlenmeyer flask containing $20 \mathrm{ml}$ of LB medium, under different conditions of temperature and $150 \mathrm{rpm}$ rotational speed.

\section{Protein Expression and Characterization}

A single colony of BL21 (DE3) cells harboring the expression recombinant vector inoculated in $5 \mathrm{ml} \mathrm{LB}$ medium supplemented with $50 \mathrm{mg} / \mathrm{l}$ kanamycin at $37{ }^{\circ} \mathrm{C}$ overnight. The pre-culture was inoculated into $20 \mathrm{ml} \mathrm{LB}$ medium at $1 \%(\mathrm{v} / \mathrm{v})$. Expression of rNAM was induced by adding 1mM IPTG when OD 600 reached to 1 . After $6 \mathrm{~h}$, the cells were harvested by centrifugation at $5000 \mathrm{x} \mathrm{g}$ for $10 \mathrm{~min}$. The harvested cells were resuspended in $0.5 \mathrm{ml}$ lysis buffer containing $100 \mathrm{mM}$ sodium phosphate buffer(pH:8), $10 \mathrm{mM}$ Tris, $0.05 \%$ Tween 20 and lysozyme $(0.1 \mathrm{mg} / \mathrm{ml})$ and incubated at $37^{\circ} \mathrm{C}$ for $20 \mathrm{~min}$. Then mixture was sonicated on ice $(5 \times 20 \mathrm{~s}$ with $20 \mathrm{~s}$ pause at amplitude 60) and centrifuged at $10000 \mathrm{x} \mathrm{g}$ for $15 \mathrm{~min}$. Total extract containing whole soluble proteins and other fractions of protein in lysate (same as insoluble proteins) separated by SDSPAGE on $10 \%$ gel using a Mini-protean Tetra Cell System (BioRad). Proteins were visualized with Coomassie Blue R-250 (BioRad).

Western blotting was performed using antibody against 6his-tagged NAM recombinant protein. The chimeric protein was transferred to a nitrocellulose membrane (sigma, USA). The membrane was blocked with 3\% BSA for 1 hour and then incubated with a monoclonal anti-6xHis tag antibody (Abcam,US) at 1:3000 dilution in PBST/BSA (PBS containing $1 \%$ tween 20 and $2 \%$ BSA) by gentle shaking at $4{ }^{\circ} \mathrm{C}$ overnight. Following membrane was incubated with HRP-conjugated goat anti mouse IgG (sigma) as secondary antibody diluted 1:5000 in PBST/BSA for 1 hour and then the membrane stained using deaminobenzidine (Sigma Aldrich, USA) solution.

Experimental Design and Optimization of Expression

Attempt to optimize overexpression of soluble rNAM protein was conducted based on RSM [2]. Four independent variable factors including post-induction temperature (factor 1), IPTG concentration (factor 2), OD600nm prior induction(factor 3 ) and post induction time (factor 4) were screened on the expression yield of recombinant chimeric protein rNAM in $E$. 
coli BL21 (DE3) using rotatable central composite design (Design Expert v. 8.0.6, Stat-Ease, Inc., Minneapolis, MN, USA). A total of 30 experimental trails were performed involving 8 star points and 6 replicates at the central points. Details of cultivation condition layout were shown in Table 2.

\section{Analytical methods for protein concentration}

\section{determination}

The expression level of rNAM in each run was measured by SDS-PAGE and quantified by image $\mathrm{J}$ densitometry quantification software (NIH) and the protein concentration was determined by the Bradford method [5] by using bovine albumin as a standard. Responses of variables were calculated using design Expert software package. Linear and quadratic coefficients were analyzed by ANOVA test. The F-test was performed for estimation of the significance of the model terms and model equation while the quality of fitted model equation was analyzed by the coefficient of determination (R2), adjusted R2 and "adequate precision". The significance of the model terms was confirmed by p-value less than 0.05. "Point optimization" process tool of Design Expert software was performed to optimize the level of each factor for maximum solubility of final product.

\section{RESULTS}

\section{Blotting}

\section{Expression of Recombinant Construct and Western}

We designed a chimeric NAM protein based on the nontoxic c-terminal domains of phospholipase $\mathrm{c}$, a truncated form of NetB that is impaired in binding and pore forming on the target cell surface and ZMP, a partial form of a zinc metallopeptidase protein. The three functional domains were separated by two hydrophobic linkers. The chimeric construct was successfully cloned into pET28a vector between the EcoRI and HidIII sites and named pET28-NAM. The recombinant construct was further confirmed by digestion and sequencing (Fig. 1). The expression of recombinant NAM was induced by addition IPTG.

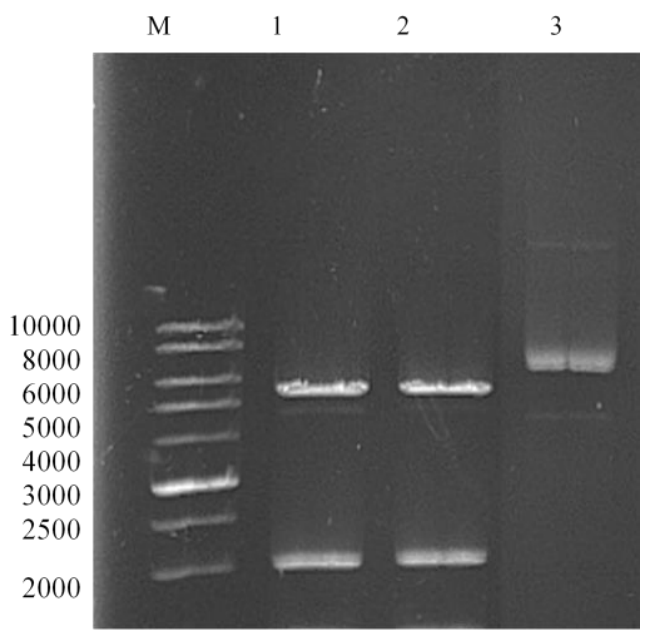

Fig. 1. Cloning validation. Lane M: DNA ladder. Lane 1 and 2: double digestion of recombinant vector with EcoRI and HindIII resulted a $2000 \mathrm{bp}$ and $5400 \mathrm{bp}$ bands corresponding to NAM and pET28a, respectively. Lane 3: single digestion pET28a/NAM resulted a $7400 \mathrm{bp}$ band.
Whole bacterial cell lysates was prepared and the total extracted protein was subjected to SDS-PAGE and a band corresponding to a $78 \mathrm{kD}$ rNAM was detected on the gel (Fig. 2 ). The majority of the rNAM protein were found as an aggregate within the inclusion body while only a small amount was detected in the soluble fraction. For confirmation anti histag antibody specially targeted chimeric protein of corresponding molecular weight to rNAM from crude bacterial cell extract (Fig. 3).

Table 2.Culture conditions and the assigned levels for each factor.

\begin{tabular}{ccccccc}
\hline Factors & unit & $\begin{array}{c}\text { Low star } \\
\text { points }\end{array}$ & $\begin{array}{l}\text { Low } \\
\text { level }\end{array}$ & $\begin{array}{l}\text { Center } \\
\text { points }\end{array}$ & $\begin{array}{l}\text { High } \\
\text { level }\end{array}$ & $\begin{array}{l}\text { High } \\
\text { Star } \\
\text { points }\end{array}$ \\
\cline { 2 - 7 } & & $-\alpha$ & -1 & 0 & +1 & $+\alpha$ \\
\hline $\begin{array}{c}\text { Post-induction } \\
\text { temperature(A) }\end{array}$ & ${ }^{\circ} \mathrm{C}$ & 19 & 25 & 31 & 37 & 45 \\
\hline $\begin{array}{c}\text { Concentration } \\
\text { of IPTG(B) }\end{array}$ & $\mathrm{mM}$ & 0.05 & 0.3 & 0.55 & 0.8 & 1.05 \\
\hline $\begin{array}{c}\text { Starting } \\
\text { induction time(C) }\end{array}$ & $\mathrm{OD}$ & 0.4 & 0.6 & 0.8 & 1 & 1.2 \\
\hline $\begin{array}{c}\text { Post } \\
\text { induction time(D) }\end{array}$ & $\mathrm{H}$ & 0.5 & 3 & 5.5 & 8 & 10.5 \\
\hline $\begin{array}{c}* \text { The central point (0) corresponds to intermediate values between the - } \\
1 \text { and +1 interval of each variable. }\end{array}$ & & & &
\end{tabular}
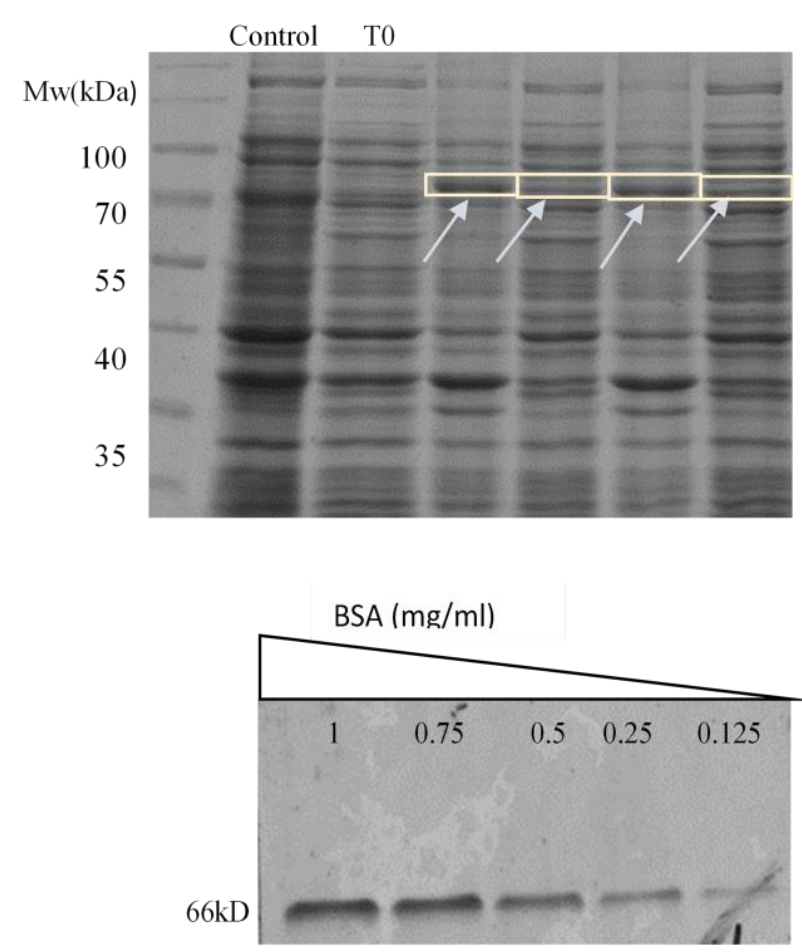

Fig.2. protein quantification using Image $J$ software. BSA standard curve was used to estimate yields of the rNAM in SDS-PAGE $10 \%$. Soluble protein fraction of induced BL21 (DE3)-pET28a/NAM cells at different runs were illustrated. Lane control: induced BL21 (DE3)-pET28a without insert. Lane T0: uninduced BL21 (DE3)-pET28a/NAM cells.

Central Composite Design and Condition of Optimized Expression

The rotatable central composite design was applied to determine optimal level of factors to maximize the expression 
rate of rNAM (Table 2). The protein expression was analyzed at 30 different expression condition and the soluble protein produced were measured and the corresponding results are represented in Table 4.

The model F-value of 37.12 indicates that the model was significant. $\mathrm{P}$-value prob $>\mathrm{F}$ less than 0.05 , imply that the model terms was significant.. In this model terms, temperature, Time, $\mathrm{OD}$ and the interaction between temperature and IPTG concentration $(\mathrm{AB})$, post induction time and cell density (OD600) (CD) were significant factors illustrated in figure 6 as contour and 3D surface plots (Table 3 and Fig. 4). The "lack of fit F-value" of 4.32 was insignificant indicated that the model was fit with observed value and was acceptable for the following experiment. Another criteria for checking the model quality is coefficient R2. The value R-squared (0.97) indicates that $97 \%$ of the total variations in system can be explained by model. In addition, the coefficient determination (R2-adjusted) of 0.94 suggested a good compatibility between actual and predicted value of expression of soluble rNAM protein.

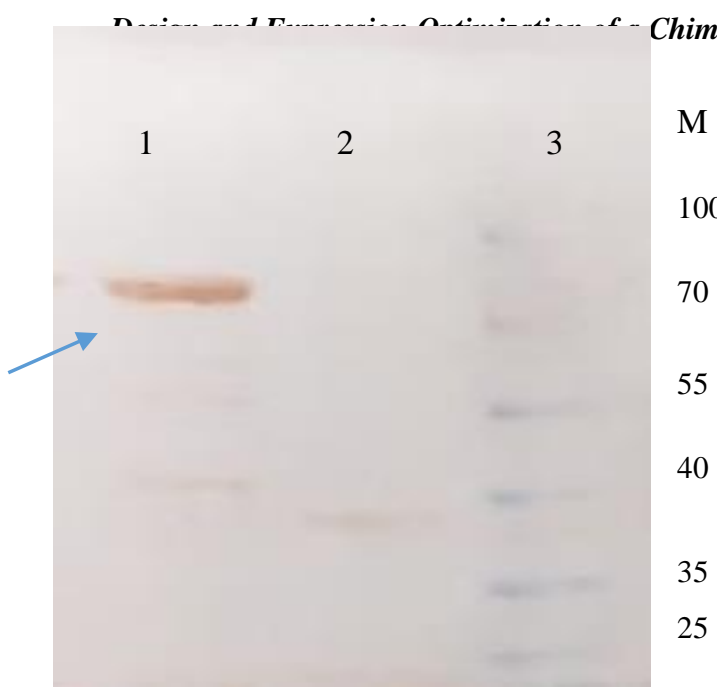

Fig 3. Western blot of expressed rNAM using anti His-tag antibody. 1: Extract of IPTG induced E. coli containing NAM construct. $\sim 78 \mathrm{kD}$. 2: uninduced $E$. coli cells (T0). 3: MW marker

In this model, Adeq precision was 24.48 indicating that there was an adequate signal.

Table 3. Analysis of ANOVA for response surface quadratic model.

\begin{tabular}{|c|c|c|c|c|c|c|c|}
\hline Source & $\begin{array}{l}\text { Sum of } \\
\text { Squares }\end{array}$ & df & $\begin{array}{l}\text { Mean } \\
\text { Square }\end{array}$ & $\begin{array}{c}\mathbf{F} \\
\text { Value }\end{array}$ & $\begin{array}{c}\text { p-value } \\
\text { Prob }>\text { F }\end{array}$ & & \\
\hline Model & 4.04 & 14 & 0.28 & 36.00 & 0.0001 & significant & \\
\hline A-temperature & 3.37 & 1 & 3.25 & 416.73 & 0.0001 & significant & \\
\hline B-IPTG & 0.027 & 1 & 0.026 & 3.32 & 0.0883 & & \\
\hline C-OD & 0.067 & 1 & 0.071 & 9.15 & 0.0085 & significant & \\
\hline D-Time & 0.31 & 1 & 0.31 & 39.18 & 0.0001 & significant & \\
\hline $\mathbf{A B}$ & 0.025 & 1 & 0.037 & 4.76 & 0.0454 & & \\
\hline $\mathbf{A C}$ & $3.875 \mathrm{E}-003$ & 1 & $1.785 \mathrm{E}-003$ & 0.23 & 0.6394 & & \\
\hline AD & $2.678 \mathrm{E}-003$ & 1 & $8.418 \mathrm{E}-003$ & 1.08 & 0.3155 & & \\
\hline BC & $4.523 \mathrm{E}-003$ & 1 & $3.875 \mathrm{E}-003$ & 0.50 & 0.4918 & & \\
\hline BD & 0.010 & 1 & 0.012 & 1.47 & 0.2435 & & \\
\hline CD & 0.035 & 1 & 0.039 & 5.01 & 0.0408 & & \\
\hline $\mathrm{A}^{2}$ & 0.055 & 1 & 0.056 & 7.15 & 0.0174 & & \\
\hline $\mathbf{B}^{2}$ & 0.079 & 1 & 0.078 & 10.02 & 0.0064 & & \\
\hline $\mathrm{C}^{2}$ & 0.017 & 1 & 0.018 & 2.26 & 0.1537 & & \\
\hline $\mathrm{D}^{2}$ & 3.709E-004 & 1 & 4.597E-004 & 0.059 & 0.8115 & & \\
\hline Residual & 0.12 & 15 & 7.804E-003 & & & & \\
\hline Lack of Fit & 0.10 & 10 & 0.010 & 4.34 & 0.0593 & not significant & \\
\hline Pure Error & 0.012 & 5 & $2.417 \mathrm{E}-003$ & & & & \\
\hline Cor Total & 4.15 & 29 & & & & & \\
\hline Std. Dev. & Mean & C.V.\% & R-Squared & \multicolumn{2}{|c|}{ Adj R-Squared } & Pred R-Squared & Adeq Precision \\
\hline 0.088 & 0.65 & 13.48 & 0.97 & \multicolumn{2}{|c|}{0.94} & 0.85 & 24.84 \\
\hline
\end{tabular}

*the p-value indicates the significance level of the variables and their interactions, Variables with $\mathrm{p}<0.05$ were considered statistically significant 
Based on multiple regression analysis, the full quadratic equation for prediction the optimal expression of rNAM soluble protein using coded factors was expressed as follows:

$\mathrm{Y}=0.64-0.37 \mathrm{~A}+0.034 \mathrm{~B}+0.053 \mathrm{C}+0.11 \mathrm{D}-0.039 \mathrm{AB}+$ $0.016 \mathrm{AC}-0.013 \mathrm{AD}+0.017 \mathrm{BC}+0.026 \mathrm{BD}-0.047 \mathrm{CD}+$ $0.045 \mathrm{~A} 2-0.054 \mathrm{~B} 2+0.025 \mathrm{C} 2+3.68 \mathrm{E}-0.03 \mathrm{D} 2$ (1)

Where $\mathrm{Y}$ as a response is the soluble rNAM production, $\mathrm{A}$, $\mathrm{B}, \mathrm{C}$ and $\mathrm{D}$ are the coded factors for four variable factors. Positive and negative effects of each factors and interaction between them are represented as plus $(+)$ and minus (-) symbols.
Different combinations of post induction temperature (19$\left.43{ }^{\circ} \mathrm{C}\right)$, IPTG concentration $(0.05-1.05 \mathrm{mM})$, OD $600 \mathrm{~nm}$ prior induction (0.4-1.2) and post induction time (0.5-10.5 h) resulted in soluble rNAM production from 0.058 to $1.48 \mathrm{mg} / \mathrm{ml}$ (Table $4)$. The lowest amount of soluble recombinant $(0.058 \mathrm{mg} / \mathrm{ml})$ was obtained at the center point of IPTG concentration, OD $600 \mathrm{~nm}$ and post induction time $(0.55 \mathrm{mM}, 0.8$ and $5.5 \mathrm{~h}$, respectively) while post induction temperature was $43{ }^{\circ} \mathrm{C}$. This result revealed that a high temperature is not favorable for

Table 4. The observed and predicted values for the expression of rNAM in E.coli under various culture condition based on CCD.

\begin{tabular}{|c|c|c|c|c|c|c|}
\hline Run & $\begin{array}{c}\text { A:Temprature } \\
\left({ }^{\circ} \mathrm{C}\right)\end{array}$ & $\begin{array}{c}\text { B: IPTG } \\
\text { concentration } \\
(\mathbf{m M})\end{array}$ & $\begin{array}{c}\text { C: cell density } \\
\left(\mathrm{OD}_{600}\right)\end{array}$ & $\begin{array}{l}\text { D: Induction time } \\
\text { (h) }\end{array}$ & $\begin{array}{l}\text { Actual response } \\
\qquad(\mathrm{mg} / \mathrm{ml})\end{array}$ & $\begin{array}{c}\text { Predicted } \\
\text { response }\end{array}$ \\
\hline 1 & 37 & 0.8 & 0.6 & 3 & 0.11 & 0.018 \\
\hline 2 & 19 & 0.55 & 0.8 & 8 & 1.48 & 1.57 \\
\hline 3 & 31 & 0.55 & 0.8 & 0.5 & 0.25 & 0.424 \\
\hline 4 & 25 & 0.8 & 0.6 & 8 & 1.25 & 1.25 \\
\hline 5 & 37 & 0.3 & 0.6 & 3 & 0.21 & 0.11 \\
\hline 6 & 37 & 0.8 & 0.6 & 8 & 0.32 & 0.37 \\
\hline 7 & 43 & 0.55 & 0.8 & 5.5 & 0.058 & 0.067 \\
\hline 8 & 25 & 0.3 & 1 & 8 & 0.97 & 1.03 \\
\hline 9 & 25 & 0.3 & 0.6 & 3 & 0.81 & 0.79 \\
\hline 10 & 37 & 0.8 & 1 & 8 & 0.39 & 0.44 \\
\hline 11 & 25 & 0.8 & 0.6 & 3 & 0.87 & 0.85 \\
\hline 12 & 31 & 0.05 & 0.8 & 5.5 & 0.27 & 0.35 \\
\hline 13 & 31 & 0.55 & 0.8 & 10.5 & 0.96 & 0.88 \\
\hline 14 & 31 & 0.55 & 0.8 & 5.5 & 0.6 & 0.63 \\
\hline 15 & 25 & 0.8 & 1 & 8 & 1.299 & 1.266 \\
\hline 16 & 31 & 0.55 & 0.8 & 5.5 & 0.64 & 0.63 \\
\hline 17 & 31 & 1.05 & 0.8 & 5.5 & 0.48 & 0.49 \\
\hline 18 & 37 & 0.3 & 0.6 & 8 & 0.34 & 0.36 \\
\hline 19 & 25 & 0.8 & 1 & 3 & 1.101 & 1.05 \\
\hline 20 & 37 & 0.3 & 1 & 3 & 0.37 & 0.311 \\
\hline 21 & 31 & 0.55 & 0.8 & 5.5 & 0.68 & 0.638 \\
\hline 22 & 37 & 0.3 & 1 & 8 & 0.42 & 0.369 \\
\hline 23 & 25 & 0.3 & 1 & 3 & 1.04 & 0.92 \\
\hline 24 & 25 & 0.3 & 0.6 & 8 & 1.13 & 1.087 \\
\hline 25 & 31 & 0.55 & 0.8 & 5.5 & 0.71 & 0.638 \\
\hline 26 & 37 & 0.8 & 1 & 3 & 0.319 & 0.28 \\
\hline 27 & 31 & 0.55 & 0.4 & 5.5 & 0.58 & 0.63 \\
\hline 28 & 31 & 0.55 & 0.8 & 5.5 & 0.58 & 0.638 \\
\hline 29 & 31 & 0.55 & 1.2 & 5.5 & 0.8 & 0.84 \\
\hline 30 & 31 & 0.55 & 0.8 & 5.5 & 0.62 & 0.63 \\
\hline
\end{tabular}



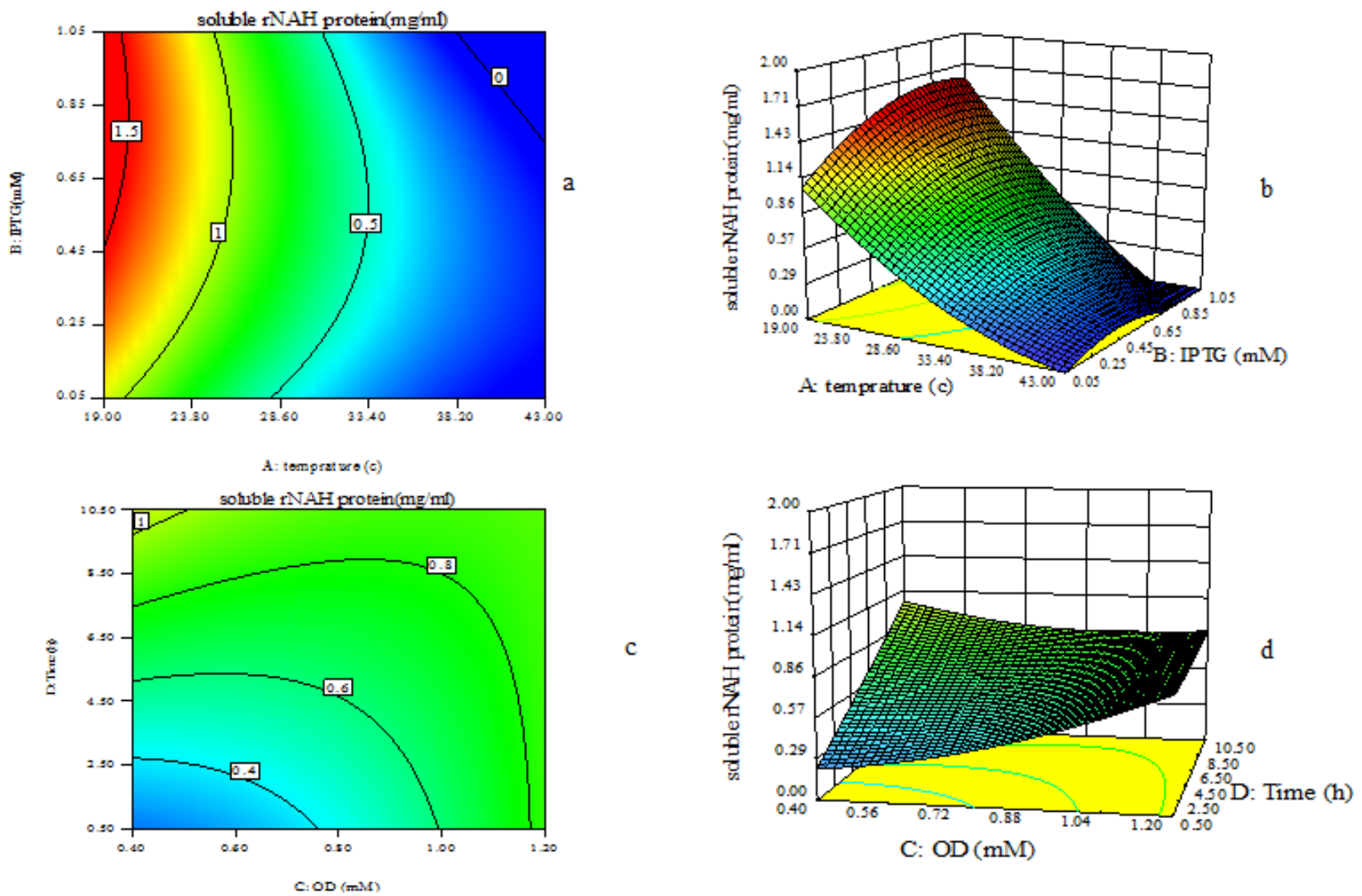

Fig. 4. 3D surface and contour curves of soluble rNAM protein showing $(a, b)$ interaction between temperature and IPTG concentration at cell density 0.8 and post induction time $5.5 \mathrm{~h},(\mathrm{c}, \mathrm{d})$ interaction between cell density and time at the post induction temperature $31{ }^{\circ} \mathrm{C}$ and IPTG concentration $0.55 \mathrm{mM}$.

rNAM production. Moreover, at the low temperature $\left(19^{\circ} \mathrm{C}\right)$ and the central point value of IPTG concentration and OD $600 \mathrm{~nm}(0.55 \mathrm{mM}$ and 0.8$)$ at the $8 \mathrm{~h}$ induction time we achieved the highest value of rNAM production. Therefore, by increasing the induction temperature above $20^{\circ} \mathrm{C}$ the higher amounts of rNAM is accumulated as inclusion body. The model's authenticity test explained that the experimentally measured values are located around the statistically predicted ones, approving the model's sufficiency (Fig. 5)

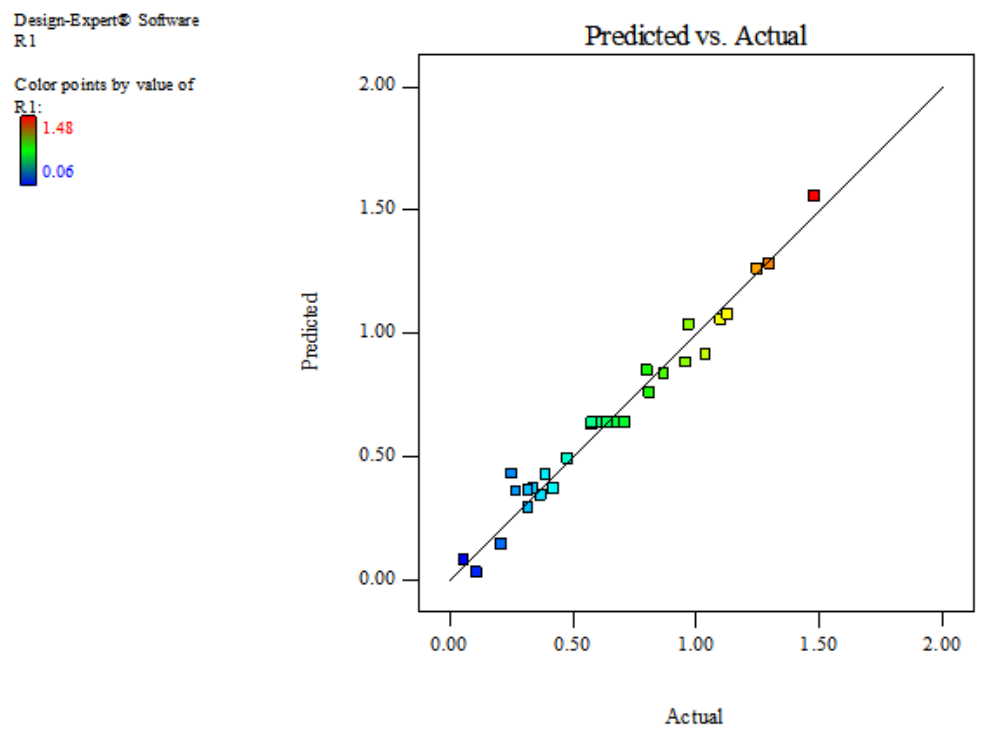

Fig 5. Linear plot of Predicted vs. actual values of soluble rNAM protein. $X$ axis: experimental value of produced rNAM under optimization process. Y axis: a prediction of produced rNAM under optimization process 


\section{DISCUSSION}

There is a growing need to develop a vaccine for NE. The designation of fusion subunit vaccine encompassing the immunogenic segments from individual toxin against NE is a promising recent approach [8]. Mot et al. and Uzal et al, have shown for protection against NE, administration of multiple antigens like Alpha-toxin and NetB toxin could elicit better immunogenicity and protection than each antigen alone [16, 32]. Rostami et al, designed a fusion protein consisting of immunogenic parts of three virulence factors of NetB-Alpha toxin-Tpel(NAT) to be used as vaccine against necrotic enteritis[27]. Most of NAT was expressed as an inclusion body. The protein was denatured, purified and refolded but the refolding efficiency of the protein was low as detected by circular dichroism analysis which could be due to the hydrophobic nature of Tpel fragment in the chimeric protein.

There are some evidences that the Tpel have little effect on pathogenesis of NE and induces partial protection against NE $[7,8]$. However, there is no consensus in this regard and some researchers believe that it increases virulence of $C$. perfringens while others found no evidence of involving Tpel in the NE pathogenesis. Moreover, it is demonstrated that metallopeptidase protein, with cell surface anchoring feature, has important role in $C$. perfringence pathogenesis [18]. This result was confirmed by Kulkarni et al., [11] which showed that immunization with metallopeptidase and PFOR as a part of multicomponent vaccine resulted in the protection against a sever challenge.

Hence, a recombinant fusion protein, rNAM, was designed using bioinformatics tools (data not shown) to preserve critical immunogenic segments of Alpha-toxin, NetB, and metallopeptidase that are involved in $C$. perfringens pathogenesis.

The bioactivity of the therapeutic proteins like subunit recombinant vaccines depends on their correct folding to induce a complete immune response. Aggregation of recombinant protein as inclusion body is one of the main problems in preparation of functional protein $[32,33]$.

In many cases the yield of production of heterologous proteins in $E$. coli, encounters with two important challenges including low expression and misfolding into insoluble aggregates. Several studies demonstrated that codon optimization has a critical role in high expression of heterologous protein. Production of plant codon optimized protein, as soluble form in E. coli in acceptable amount is considered to be major obstacles in using one gene sequence for both systems [4,13]. Moreover, only 30-50\% of recombinant proteins produced in E. coli are sufficiently soluble [13,17].

Firstly, due to higher percentage of rare codons, and codon adaptation index of $63 \%$ for E.coli the rNAM is expressed poorly (Table 1). This is in accordance with Menzella et al. study. They have shown that the CAI of $66 \%$ resulted in reduced production of chymosin in E. coli [15].

The solubility of rNAM produced at standard growth condition (run 1, Table 4) in E. coli was less than refolded form. This could be as a result of changes in secondary structure of refolded rNAM compared to the native form that was shown by data obtained from circular dichroism analysis (manuscript under review). Different approaches are designed to eradicate the inclusion bodies including codon optimization strategy, fusion tags utilization [22], changing the expression host [9], and culture condition [26, 14, 29] such as lower growth temperature [24].
Rigi et al. [29] reported that 5 fold productivity of Staphylococcal protein A was attained using culture condition optimization by RSM. Using the same method Papaneophytou et al. [22] has reported increasing up to $11 \%$ of the soluble TNF- $\alpha$ after determination of optimum induction conditions in E. coli.

Our results is in accordance with the above studies. In this study, application of RSM software has resulted in Table 3 presenting modifications of parameters for increasing production of soluble protein. The results of optimum response by regression equation using coded factors fitted to a secondorder poly-nominal mode (Eq.(1)) defined that the linear coefficients A (temperature), C (starting time induction) and D (induction time), unlike the linear coefficient B (IPTG concentration) have a positive effect on production of soluble rNAM Although, the interactions between temperature and inducer concentrations were statistically significant where pvalue was $0.045 \mathrm{Such}$ as modification of the growth temperature had the most significant effect.

The maximum enhanced soluble rNAM protein production was found in run 2 that revealed that lower postinduction temperature at $20^{\circ} \mathrm{C}$. This is in accordance with Volonte et al. [35] that have reported the highest productivity of soluble recombinant glutaryl-7-aminocephalosporanic acid acylase (GLA) was achieved by lowering temperature from 37 to 25. An increase in the amount of Tumor Necrosis Factor- $\alpha$ at lower temperature has also been reported [23]. Furthermore, several studies have demonstrated that culturing at low temperatures, due to a decrease in many metabolic processes can lead to a higher yield of the soluble fraction of many proteins [21, 19, 29, 1].

Based on results of this study, post-induction time is also an important factor, the longer post induction time resulted in a higher production of soluble rNAM, and thus maximum $8 \mathrm{~h}$ was selected as the optimized induction time.

In this study, the IPTG concentration showed insignificant effect on production of soluble form (Table 3 ). Therefore, based on optimum level of other three factors for obtaining the highest yield, the RSM software has proposed $0.55 \mathrm{mM}$ for IPTG concentration. This is in accordance with Shafiee et al., and Ramirez et al.,[25, 30]. who demonstrate that the inducer concentration lower than $1 \mathrm{mM}$ does not affect the expression level of the recombinant protein.

The represented experimental data showed that the production of the soluble rNAM was maximized when post induction temperature, IPTG concentration, the starting time of induction and duration of induction were $19^{\circ} \mathrm{C}, 0.55 \mathrm{mM}, 0.8$ and $8 \mathrm{~h}$ respectively. Based on the prediction of Design Expert, the optimum condition for highly production of soluble rNAM were achieved at $20.36{ }^{\circ} \mathrm{C}$ with, $0.49 \mathrm{mM}$ of IPTG, an OD600 of 0.8 for start of the induction, and $7.85 \mathrm{~h}$ of induction time for the predicted rNAM production of $1.57 \mathrm{mg} / \mathrm{ml}$. Therefore, the optimization process led to 7.39 fold increase in the soluble protein fraction (i.e. $1.48 \mathrm{mg} / \mathrm{ml}$ versus $0.2 \mathrm{mg} / \mathrm{ml}$ ) (Table 4).

In summary, this research is the first report presenting the data on optimization the expression of subunit candidate vaccine rNAM against avian necrotic enteritis in E. coli, using RSM methodology. We demonstrated that with limited number of experiments will facilitate 7 fold increase in production of soluble protein. The data would increase the knowledge of expression of heterologous proteins for research and industrial applications. 


\section{ACKNOWLEDGEMENT}

This research was financially supported in part by grant No. 951106 of Biotechnology Development council of the Islamic Republic of Iran and Iran National Science Foundation by project No. 96006074. The authors would like to thank the Genetics and Agricultural Biotechnology Institute of Tabarestan (GABIT), Sari Agriculture Science and Natural Resource University (SANRU), National Institute of Genetic Engineering and Biotechnology (NIGEB) for providing the necessary equipment.

\section{CONFLICT OF INTEREST}

The authors declare that they have no conflict of interest.

\section{REFERENCES}

1. Arjomand MR, Ahmadian G, Habibi-Rezaei M, Hassanzadeh M, Karkhane AA, Moosavi-Movahedi AA et al. The importance of the nonactive site and non-periodical structure located histidine residue respect to the structure and function of exo-inulinase. International journal of biological macromolecules. 2017;98:542-9.

2. Baron A. Experimental designs. The Behavior Analyst. 1990;13(2):167.

3. Beigi L, Karbalaei-Heidari HR, Kharrati-Kopaei M. Optimization of an extracellular zinc-metalloprotease (SVP2) expression in Escherichia coli BL21 (DE3) using response surface methodology. Protein expression and purification. 2012;84(1):161-6.

4. Benita Y, Wise MJ, Lok MC, Humphery-Smith I, Oosting RS. Analysis of high throughput protein expression in Escherichia coli. Molecular \& Cellular Proteomics. 2006;5(9):1567-80.

5. Bradford MM. A rapid and sensitive method for the quantitation of microgram quantities of protein utilizing the principle of protein-dye binding. Analytical biochemistry. 1976;72(1-2):248-54

6. Das S, Majumder S, Kingston JJ, Batra HV. Generation and characterization of recombinant bivalent fusion protein r-Cpib for immunotherapy against Clostridium perfringens beta and iota toxemia. Molecular immunology. 2016;70:140-8.

7. Fernandes da Costa SP, Mot D, Geeraerts S, Bokori-Brown M, Immerseel FV, Titball RW. Variable protection against experimental broiler necrotic enteritis after immunisation with the C-terminal fragment of Clostridium perfringens alpha-toxin and a non-toxic NetB variant. Avian Pathology. 2015(just-accepted):1-26

8. Fernandes da Costa SP, Savva CG, Bokori-Brown M, Naylor CE, Moss DS, Basak AK et al. Identification of a key residue for oligomerisation and pore-formation of Clostridium perfringens NetB. Toxins. 2014;6(3):104961.

9. Han J-H, Choi Y-S, Kim W-J, Jeon YH, Lee SK, Lee B-J et al. Codon optimization enhances protein expression of human peptide deformylase in E. coli. Protein expression and purification. 2010;70(2):224-30.

10. Kulkarni R, Parreira V, Jiang Y-F, Prescott J. A live oral recombinant Salmonella enterica serovar Typhimurium vaccine expressing Clostridium perfringens antigens confers protection against necrotic enteritis in broiler chickens. Clinical and Vaccine Immunology. 2010;17(2):205-14.

11. Kulkarni R, Parreira V, Sharif S, Prescott J. Immunization of broiler chickens against Clostridium perfringens-induced necrotic enteritis. Clinical and Vaccine Immunology. 2007;14(9):1070-7.

12. Kulkarni R, Parreira V, Sharif S, Prescott J. Oral immunization of broiler chickens against necrotic enteritis with an attenuated Salmonella vaccine vector expressing Clostridium perfringens antigens. Vaccine. 2008;26(33):4194-203.

13. Leibly DJ, Nguyen TN, Kao LT, Hewitt SN, Barrett LK, Van Voorhis WC. Stabilizing additives added during cell lysis aid in the solubilization of recombinant proteins. PLoS One. 2012;7(12):e52482.

14. Maldonado LMP, Hernández VEB, Rivero EM, de la Rosa APB, Flores JLF, Acevedo LGO et al. Optimization of culture conditions for a synthetic gene expression in Escherichia coli using response surface methodology: the case of human interferon beta. Biomolecular engineering. 2007;24(2):217-22.

15. Menzella HG. Comparison of two codon optimization strategies to enhance recombinant protein production in Escherichia coli. Microbial cell factories. 2011;10(1):15.

16. Mot D, Timbermont L, Haesebrouck F, Ducatelle R, Van Immerseel F. Progress and problems in vaccination against necrotic enteritis in broiler chickens. Avian Pathology. 2014;43(4):290-300.

17. Myler P, Stacy R, Stewart L, Staker B, Van Voorhis W, Varani G et al. The seattle structural genomics center for infectious disease (SSGCID). Infectious Disorders-Drug Targets (Formerly Current Drug TargetsInfectious Disorders). 2009;9(5):493-506.

18. Nakjang S, Ndeh DA, Wipat A, Bolam DN, Hirt RP. A novel extracellular metallopeptidase domain shared by animal host-associated mutualistic and pathogenic microbes. PLoS One. 2012;7(1):e30287.

19. Nygaard FB, Harlow KW. Heterologous expression of soluble, active proteins in Escherichia coli: the human estrogen receptor hormone-binding domain as paradigm. Protein expression and purification. 2001;21(3):500-9. 20. Oskouie SFG, Tabandeh F, Yakhchali B, Eftekhar F. Response surface optimization of medium composition for alkaline protease production by Bacillus clausii. Biochemical Engineering Journal. 2008;39(1):37-42.

21. Pan H, Xie Z, Bao W, Zhang J. Optimization of culture conditions to enhance cis-epoxysuccinate hydrolase production in Escherichia coli by response surface methodology. Biochemical Engineering Journal. 2008;42(2):133-8.

22. Papaneophytou CP, Kontopidis G. Statistical approaches to maximize recombinant protein expression in Escherichia coli: a general review. Protein expression and purification. 2014;94:22-32.

23. Papaneophytou CP, Rinotas V, Douni E, Kontopidis G. A statistical approach for optimization of RANKL overexpression in Escherichia coli: purification and characterization of the protein. Protein expression and purification. 2013;90(1):9-19.

24. Qing G, Ma L-C, Khorchid A, Swapna G, Mal TK, Takayama MM et al Cold-shock induced high-yield protein production in Escherichia coli. Nature biotechnology. 2004;22(7):877.

25. Ramirez O, Zamora R, Espinosa G, Merino E, Bolivar F, Quintero R. Kinetic study of penicillin acylase production by recombinant E. coli in batch cultures. Process Biochemistry. 1994;29(3):197-206.

26. Rigi G, Mohammadi SG, Arjomand MR, Ahmadian G, Noghabi KA Optimization of extracellular truncated staphylococcal protein A expression in Escherichia coli BL21 (DE3). Biotechnology and applied biochemistry. 2014;61(2):217-25.

27. Rostami A, Goshadrou F, Langroudi RP, Bathaie SZ, Riazi A, Amani J et al. Design and expression of a chimeric vaccine candidate for avian necrotic enteritis. Protein Engineering, Design and Selection. 2016;30(1):39-45.

28. Savva CG, da Costa SPF, Bokori-Brown M, Naylor CE, Cole AR, Moss DS et al. Molecular architecture and functional analysis of NetB, a poreforming toxin from Clostridium perfringens. Journal of Biological Chemistry. 2013;288(5):3512-22

29. Schlegel S, Löfblom J, Lee C, Hjelm A, Klepsch M, Strous M et al. Optimizing membrane protein overexpression in the Escherichia coli strain Lemo21 (DE3). Journal of molecular biology. 2012;423(4):648-59.

30. Shafiee F, Rabbani M, Jahanian-Najafabadi A. Optimization of the Expression of DT386-BR2 Fusion Protein in Escherichia coli using Response Surface Methodology. Advanced biomedical research. 2017;6.

31. Shreya D, Uppalapati SR, Kingston JJ, Sripathy MH, Batra HV. Immunization with recombinant bivalent chimera r-Cpae confers protection against alpha toxin and enterotoxin of Clostridium perfringens type $\mathrm{A}$ in murine model. Molecular immunology. 2015;65(1):51-7.

32. Singh SM, Panda AK. Solubilization and refolding of bacterial inclusion body proteins. Journal of bioscience and bioengineering. 2005;99(4):30310 .

33. Sørensen HP, Mortensen KK. Soluble expression of recombinant proteins in the cytoplasm of Escherichia coli. Microbial cell factories. 2005;4(1):1.

34. Uzal FA, Freedman JC, Shrestha A, Theoret JR, Garcia J, Awad MM et al. Towards an understanding of the role of Clostridium perfringens toxins in human and animal disease. Future microbiology. 2014;9(3):361-77.

35. Volontè F, Marinelli F, Gastaldo L, Sacchi S, Pilone MS, Pollegioni L et al. Optimization of glutaryl-7-aminocephalosporanic acid acylase expression in E. coli. Protein expression and purification. 2008;61(2):131-7. 